УДК 37.018.1(477)

(C) Ворожбіт-Горбатюк В.В., Волкова Я.В., 2019 р.

http://orcid.org/0000-0002-5138-9226

http://orcid.org/0000-0002-0450-7453

DOI: $10.34142 / 23128046.2019 .46 .03$

В. В. Ворожбіт-Горбатюк

Я. В. Волкова

\title{
ДОСВІД ФІНЛЯНДІЇ ЩОДО ОРГАНІЗАЩЇ̈ ВИХОВАННЯ БАТЬКІВ УЧНІВ: ЦІЛЬОВИЙ І ЗМІСТОВИЙ КОМПОНЕНТИ
}

Стаття присвячена аналізу досвіду визначення цільових $і$ змістових компонентів виховання батьків у Фінляндї. Проведено науковий аналіз ступеня розробки проблеми. Указано, щуо досвід Фінляндії є цінним, не суперечить изіннісним пріоритетам украӥнської парадигми освіти і до изього часу не був предметом окремого дослідження. $У$ ході проведення дослідження визначено особливості иүільного компонента виховання батьків учнів у Фінляндї. Зокрема, зазначено про те, щзо основою розвитку дитини у цій країні визначено забезпечення батьками або компенсування освітнім закладом добробуту дитини, створення середовищза відчуття радості, успіху. Така орієнтація суттєво відрізняється від практики украӥнського досвіду організації педагогічної просвіти батьків. Конкретизовано той факт, щзо головне завдання виховання батьків у изій краӥні полягає в формування у них бачення ходу дитячого зростання, їхнього розвитку та навчальних можливостей, коли доросла людина підтримує та наставляє фізично, психологічно, соціально, пізнавально й емоційно, попереджує труднощі, щзо можуть виникнути.

У статті наголошено на тому, щзо провідним принцииом організащіі виховання батьків у Фінляндї є інтеграція. Зміст інтегративної просвіти забезпечується темами, пов'язаними зі сферою дитячого життя, аналізом змісту дитячих поглядів на світ. Цілі такої інтегративної просвіти батьків сумісно договірні та визнані середовищним суспільством, у якому живуть діти. Авторами зазначено, щуо у Фінляндї діє система універсального розвитку дітей у ранньому віці, система патронування $i$ допомоги в організації догляду за дітьми, система охорони здоров'я, розгалужена система громадських бібліотек.

Аналіз публікацій, дописів численних форумів батьків, спілкування 3 фінами засвідчило, щуо під час планування проблематики зустрічей чи занять з батьками і дітьми беруться до уваги різні галузі знань і розглядаються як частина обраної теми. Вибір тематичних модулів має за мету залучення батьків і дітей до планування занять.

Новизна змістового компоненту забезпечується інтеграційним підходом у визначенні змісту занять і створенням розгалуженої мережі 
установ додаткових освітніх послуг у сфері спорту, мистецтва, культури, організаиії спільного дозвілля.

Ключові слова: батьки, дитина, інтеграція, цүілі виховання, розвиток, вихователі, підготовка, системність, суспільні изінності.

Vorozhbit-Horbatiuk V.V., Volkova Ya. V. Finnish experience in the organization of training students' parents: target and substantial components. The article is devoted to the analysis of the experience of determining the target and substantial components of training parents in Finland. A scientific analysis of the problem development degree has been conducted by scholars. It has been stated that the experience of Finland is valuable, does not contradict the value priorities of the Ukrainian paradigm of education, has never been the subject of a separate study. In the course of the scientific research the peculiarities of the substantial component of training students' parents in Finland have been determined. In particular, it has been noted that the basis for a child's development in this country is the provision of a child's welfare by parents or compensating by the educational institution, creating conditions when children feel joy, success. This orientation is very different from the practice of the Ukrainian experience in organizing pedagogical education of parents. There is a fact that the main task of training parents in this country is the formation of their understanding of the child's growth, development and learning opportunities, when the adult maintains and teaches physically, psychologically, socially, cognitively and emotionally, prevents the difficulties that may arise.

The article emphasizes that the main principle of the organization of training parents in Finland is integration. The content of integrating education is provided by topics related to childhood, by the analysis of the content of children's views on the world. The goals of such an integrative education of parents are consistently contractual and approved by the environmental community in which children live. The authors state that in Finland there is a system of universal early childhood development, a system of patronage and assistance in the organization of child care, a health care system, an extensive system of public libraries.

The analysis of publications, numerous message boards for parents and communication with Finns has testified that different branches of knowledge are taken into account and considered as part of the chosen topic during the planning of the issues of meetings or classes with parents and children. The choice of the thematic modules is intended to involve parents and children in the planning of classes.

The novelty of the substantial component is provided by the integration approach in determining the content of classes and creating an extensive network of institutions for additional educational services in the field of sports, art, culture, and organization of joint leisure activities.

Keywords: parents, child, integration, goals of education, development, educators, training, systemacity, social values. 
Вступ. Демократичні перетворення в Україні і світі зорієнтовані на піднесення рівня розвитку культури громадян, зокрема - педагогічної. Це завдання унормоване Законом України «Про освіту», Національною доктриною розвитку освіти. У зазначених документах наголошено на важливості родинного виховання та забезпечення педагогічної просвіти батьків як важливої ланки загального виховного процесу. Особливо цінним $є$ організація виховання батьків із урахуванням цінного досвіду Фінляндії. Спостереження життя фінів свідчить про те, що батьки у Фінляндії вміють радіти життю, народженню і вихованню дітей, насолоджуватися цією радістю.

Визнання високого рівня педагогічної культури громадян у цій країні, функціонування різних інституцій просвіти батьків у кожній спільноті (регіоні), а також у межах усієї країни зумовлює значущість предмета започаткованого дослідження. На початку XXI ст. уряд України демонструє усвідомлення прихованих проблем пострадянського простору у педагогічному всеобучі батьків, зокрема мова йде про домінування суспільного виховання дітей та нівелювання цінностей родини як вирішального осередку становлення особистості. Сьогодення вимагає більш дієвих форм організації родинного виховання i навчання дітей $\mathrm{y}$ полікультурних умовах на основі позитивного світового педагогічного досвіду.

Цим визначено актуальність проведення компаративного аналізу традицій і досвіду виховання батьків учнів в Україні і Фінляндії.

Аналіз основних досліджень і публікацій свідчить про те, що проблематика організації виховання батьків не нова. Детальний науковий аналіз народного педагогічного досвіду представлено у працях Т. Лозко, Є. Сявавко, М. Стельмаховича, порівняльно-педагогічний аспект проблеми висвітлено у наукових розвідках Т. Вечерок, Г. Фінчук, О. Ярошевської. 
Мета та завдання. Mema cmammi: узагальнити досвід Фінляндії щодо визначення цілей і змісту виховання батьків для якісного покращення відповідної педагогічної просвіти в Україні.

Методи дослідження. Для досягнення мети дослідження було застосовано такі методи: теоретичні - аналіз психолого-педагогічної літератури 3 метою визначення ступеня наукової розробки проблеми; порівняльний та критичний аналіз, систематизація, узагальнення - для визначення провідних категорій дослідження; емпіричні - спостереження педагогічного досвіду, огляд інформаційних ресурсів і форумів батьків і педагогів для аналізу цільового і змістового компонентів виховання батьків учнів у Фінляндії.

Результати. Виховання батьків у Фінляндії будується на головних суспільних цінностях, які обумовлені в національному законодавстві та міжнародних деклараціях, рекомендаціях або договорах, що прагнуть захистити права людини. Роль педагогічної просвіти чи всеобучу у Фінляндії полягає у підготовці батьків до усвідомлення цінності розвитку дітей як особистостей та духовно відповідальних членів суспільства. Найважливіший засіб виховання у Фінляндії - показати людині відповідні вчинки згідно із загальноприйнятими правилами й оцінкою інших людей. На відміну від досліджуваної країни, у національній освітній системі акцент робиться на узгодження з національними культурними цінностями і традиціями.

Варто зазначити, що в Україні батьківська педагогічна просвіта спрямована передусім на подолання проблем, пов'язаних із соціальною адаптацією, попередженням чи подоланням прихованої бездоглядності, розв'язання питань конфліктного змісту. Сьогодення взаємодії батьків і дітей в українських родинах багато у чому зорієнтоване на організацію і користування системою додаткових освітніх послуг. Нажаль, тенденція, коли батьки уважають, що спеціально організоване середовище і педагог краще забезпечить виховання дитини порівняно з родинним виховним впливом, нині переважає. 
На наш погляд, це викликано стрімкими реформами в освітній галузі. Посилення прагматизму, нестабільність соціально-економічного становища змушують батьків розглядати виховання дітей як системне накопичення знань, компетенцій, які можуть у майбутньому стати в пригоді. У такій ситуації страждає власне родинне спілкування і взаємодія батьків і дитини. Феномен відчуття успіху, задоволення собою й іншими нівелюється i перетворюється на абстракцію.

Інакше формується цільовий компонент у Фінляндії. Фіни роблять акцент на створення умов систематичного неперервного спілкування i взаємодії дитини в родинному колі. Провідна роль у вихованні батьків у цій країні полягає в формуванні у батьків бачення ходу дитячого зростання, розвитку та навчальних можливостях, коли доросла людина підтримує та наставляє фізично, психологічно, соціально, пізнавально й емоційно, попереджує труднощі, що можуть виникнути (Zashchita detei, 2019). Це дуже важливо для зміцнення у дитини здорового почуття самоповаги за допомогою позитивних навчальних вражень. Це забезпечує можливості для взаємодії з іншими людьми. Українські батьки питанням самоповаги, формування досвіду комфортної соціалізації приділяють набагато менше уваги.

Перегляд інформації на численних батьківських форумах, спілкування 3 фінами - батьками і молоддю дає підстави для висновку, що світ спілкування батьків і дитини у Фінляндії наповнений різноманітними враженнями, збагачується, допомагає маленькій людині знайти нові сфери інтересів. В Україні ж акцент робиться на популярні методики раннього розвитку дитини. Нажаль, наслідки використання елементів всесвітньо визнаних методик раннього різноманітного розвитку дитини часто нівелюються через несистематичність їх використання, формалізм у педагогічній просвіті самих батьків, які переважно захоплюються самою ідеєю, без звернення до детального вивчення потреб і інтересів дитини. 
Варто наголосити на тому, що у Фінляндії багато уваги приділено спеціальним потребам дівчаток і хлопчиків. Традиційно в Україні це питання так само реалізоване. Однак, сьогодення української молодіжної субкультури демонструє низку прихованих проблем освітнього порядку, зокрема. Це так само актуалізує значимість запропонованої наукової розвідки.

Звернемо увагу на те, що виховання батьків у Фінляндії базується на інтеграції. Зміст інтегративної просвіти забезпечується темами, пов'язаними зі сферою дитячого життя, з одного боку, та аналізом змісту дитячих поглядів на світ, - 3 іншого. Цілі такої інтегративної просвіти батьків сумісно договірні та визнані середовищним суспільством, у якому живуть діти. Для того, щоб допомогти дитині досягти успіху, у Фінляндії діє система універсального розвитку дітей у ранньому віці, система патронування i допомоги в організації догляду за дітьми, система охорони здоров'я, розгалужена система громадських бібліотек (Voker, 2018).

Варто наголосити, що різноманітність інтеграції можна побачити у тому, що під час планування проблематики зустрічей чи занять з батьками $\mathrm{i}$ дітьми беруться до уваги різні галузі знань і розглядаються як частина обраної теми. Вибір тематичних модулів має за мету залучення батьків і дітей до планування занять.

Вивчення матеріалів із теми дослідження свідчить про те, що Фінляндія на одне 3 перших місць в організації освіти взагалі висуває чіткі механізми забезпечення і посилення благополуччя і здоров'я дітей в усіх закладах освіти. Для досягнення цього завдання у Фінляндії є нормою забезпечення освітніх установ достатніми ресурсами і кадрами (Voker, 2018). Кожний навчальний заклад у цій країні має групу із забезпечення учнівського добробуту. До складу таких груп входять учителі, батьки, вихователі, експерти, керівництво освітніми установами. Члени цих груп обговорюють поточні проблеми, пропонують кращі способи їх вирішення. Україна, як i Фінляндія, успіх дитини визначає серед завдань у системі пріоритетів, однак, 
знову заважає формальний підхід щодо організації додаткових чи спеціальних освітніх послуг.

Перше завдання фінського педагога - переконатися в тому, що відсутність необхідного мінімуму заходів i засобів по догляду за підтриманням здоров'я дитини в домашніх умовах не зменшує шанси дитини на успіх. В українській школі і родині надзвичайно часто використовується принцип змагальності, культивується прагнення дитини досягти першості. Однак бути першим не завжди означає стати успішним. Це, уважаємо, надзвичайно важливим аспектом у формуванні цільових i змістових компонентів батьківської просвіти в Україні.

Цікавим видається той факт, що узагальнення досвіду та інформації щодо взаємодії з дорослими та дітьми у різних сферах життєдіяльності формує провідну складову освітніх компетенцій. Використання методів роботи з батьками і дітьми передбачає отримання різного досвіду і навичок із різних галузей знань, що сприяє розширенню світогляду особистості, ऑii самореалізації. Поділ батьківської просвіти на предмети скеровується не лише вчителем, але часто - батьками та їхніми дітьми (Эмиграция и жизнь в Финляндии - личный опыт, 2019).

Виховне середовище у змістовому аспекті батьківської просвіти спирається на фізичне, психологічне, соціальне, пізнавальне та емоційне оточення, в якому перебуває родина. Невід'ємні фактори змісту батьківської просвіти - домінуюча атмосфера у виховному середовищі дитини. Батьків навчають у першу чергу в спілкуванні і будь-якій взаємодії з дітьми бути веселими, відкритими та повільними (Roditelstvo v Finliandii, 2019). Цьому ж батьки повинні навчити і дітей. Як відомо, інструменти та робочі матеріали допомагають дитині стати повноправним членом сучасного інформаційного суспільства. Фіни переконані у тому, що виховне середовище має бути здоровим і в різних напрямах допомагати дитячій безпеці та надійності. У спільній роботі з батьками та дітьми вихователь планує, забезпечує й 
визначає такі види діяльності, які ведуть до розвитку позитивних дитячих емоцій, конструктивних умінь і знань, розширюють інтереси дитини.

У Фінляндії, як і в Україні, батьки несуть відповідальність за виховання дітей. Загальна підтримка, яка забезпечується різними способами батьківської просвіти, відбувається завдяки співробітництву з батьками або опікунами, які несуть відповідальність за виховання і освіту дітей. 3 точки зору дитячого задоволення, зростання та навчання, важливо будувати відносини на довірі між персоналом освітньої установи та батьками або опікунами.

Варто звернути увагу на позитивну практику Фінляндії щодо педагогічної просвіти батьків. Зокрема, на початковому етапі дошкільного навчання вихователь складає план розвитку партнерства з батьками. Мета такого плану - гарантувати вихованцю найкращі можливості зростання та різнобічного навчання. План дитячого дошкільного навчання складається окремо для кожної дитини або спільно - для групи. У такому плані акцентується увага на чинниках, необхідних для індивідуального розвитку дитячої особистості (особливості дитячого зростання, тенденції розвитку та дитячі проблеми).

Наголосимо на тому, що у Фінляндії чітко усвідомлюють той факт, що зміни у шкільному навчанні значною мірою пов’язані з тим, що відбувається 3 дитиною поза межами школи. Варто також зауважити, що у країні, яка вивчається, родинні обставини меншою мірою впливають на успіхи дитини, ніж в Україні, оскільки в Фінляндії забезпечено особливу політику в інтересах дітей і молоді спільно 3 широкою мережею асоціацій, клубів, організацій. Їх метою $\epsilon$ створення середовища позитивного впливу на благополуччя, здоров’я, соціальний статус дітей. У Фінляндії станом на 2016 рік діє понад 100000 неурядових асоціацій. Це свідчить про те, що троє 3 п’яти фінських дітей віком до 18 років займаються якимось із видів соціальної активності. Найпоширенішими напрямами роботи асоціацій $\epsilon$ 
спорт, мистецтво, культура. 90\% фінів указують на те, що мають принаймні одне захоплення поза межами школи (Voker, 2018).

Обговорення. Освіта i розвиток особистості дитини у Фінляндії відбуваються природним шляхом. Особлива увага для досягнення дитиною успіху приділяється добробуту i збереженню здоров'я. Першочергове завдання виховання батьків у зазначеній країні - з’ясувати рівень добробуту дитини. Батьки отримують перші рекомендації щодо забезпечення фізичного, емоційного і психічного здорового стану дитини. Прагнення учителів, вихователів, експертів і батьків - зробити дорослішання дитини радісним. Високий рівень радості у фінському підході до виховання батьків доповнюється і такими важливими елементами, як: новизна і незалежність. На рівні свободи дій батьки мають забезпечити дитині право самій робити вибір, обирати захоплення, напрям розвитку тощо.

Це суттєво відрізняє фінський підхід від України. 3 дитинства фіни вчаться робити вибір, керуючись власними критеріями, які не суперечать соціальним ціннісним установам. Тому незалежність характеризує цю націю в цілому. Новизна забезпечується інтеграційним підходом до визначення змісту занять і створення розгалуженої мережі установ додаткових освітніх послуг. Фінська школа підтримує і заохочує дітей проявляти ініціативу в організації активного дозвілля. Маленькі фіни отримують життєво важливий досвід - брати на себе відповідальність, втілювати власні ідеї, виділяти час і простір для організації активних ігор з іншими.

Будь-яка справа, заняття організовуються згідно з природним ритмом людини. Це передбачає часті короткі перерви через кожні 30-45 хвилин. Таким чином, зберігається зосередженість і не втрачається інтерес до обраної справи.

Висновки. Підсумовуючи короткий аналіз цільового і змістового компонентів виховання батьків учнів у Фінляндії, зазначимо, що головна увага у визначенні цілей виховання батьків спрямована на формування досвіду забезпечити добробут для розвитку дитини. Бути успішним для 
фінської дитини означає жити за природним ритмом, радіти кожному новому заняттю, мати право робити власний вибір i нести відповідну відповідальність. Змістовий аспект виховання батьків учнів у Фінляндії реалізується через принципові категорії інтеграції (заняття поза межами освітнього закладу можуть бути не пов'язані 3 навчанням, напрями визначаються за участю самих дітей і батьків, часто діти старшого віку можуть бути організаторами дозвілля дітей меншого віку), належності до спільноти (бути членом родини, експертом, вихователем, будувати відносини, спільні плани - почесно для усіх).

\section{ЛITEPATУРА:}

Защита детей. Режим доступу: https://mnogodetok.ru/viewtopic.php?t=37597

Родительство в Финляндии. Режим доступу: https://culturas.fi/ru/diskussionnaya-grupparoditelstvo-v-finlyandii-montessori-pedagogika

Тімоті Д. Вокер Як навчають у Фінляндії. Найкраща шкільна освіта. Пер. 3 англ. Н. Лавської. К. : Видавнича група КМ-БУКС, 2018. 232 с.

Эмиграция и жизнь в Финляндии - личный опыт. Режим доступу: https://lifetrip.ru/emigraciya-i-zhizn-v-finlyandii-lichnyj-opyt/

\section{REFERENCES:}

Emihratsiia $i$ zhyzn v Finliandii - lichnyi opyt (2019). [Emigration and living in Finland is a personal experience]. Retrieved from: https://life-trip.ru/emigraciya-i-zhizn-v-finlyandiilichnyj-opyt/ (in Russian).

Roditelstvo $v$ Finliandii (2019). [Parenthood in Finland]. Retrieved from: https://culturas.fi/ru/diskussionnaya-gruppa-roditelstvo-v-finlyandii-montessoripedagogika (in Russian).

Timoti D. Voker (2018). Yak navchaiut u Finliandii. Naikrashchf shkilna osvita. [How to teach in Finland. The best school education]. (Trans. from English). Kyiv : Vydavnycha hrupa KM-BUKS (in Ukranian).

Zashchita detei (2019). https://mnogodetok.ru/viewtopic.php?t=37597 (in Russian).

Інформація про авторів:

Ворожбіт-Горбатюк Вікторія Вікторівна: ORCID: http://orcid.org/ 0000-0002-04507453, доктор педагогічних наук, професор, професор кафедри історії педагогіки i порівняльної педагогіки Харківського національного педагогічного університету імені Г. С. Сковороди, вул. Валентинівська, 2, Харків, Україна, 61000.

e-mail: gorbatykvv@ukr.net

\section{Information about the authors:}

\section{Vorozhbit-Horbatiuk Viktoriia Viktorivna:}

ORCID: http://orcid.org/ 0000-0002-0450-

7453, Dr. hab. in Pedagogy, Professor,

Professor of History of Pedagogy and

Comparative Pedagogy Department, H. S.

Skovoroda Kharkiv National Pedagogical

University, Valentynivska street, 2, Kharkiv, Ukraine, 61000.

e-mail: gorbatykvv@ukr.net

Волкова Яна Вадимівна: ORCID: Volkova Yana Vadymivna: ORCID: 
http://orcid.org/ 0000-0002-0450-7453, http://orcid.org/ 0000-0002-0450-7453, Ph.D. аспірантка кафедри історії педагогіки i candidate of the Department of History of порівняльної педагогіки Харківського Pedagogy and Comparative Pedagogy, H. S. національного педагогічного університету Skovoroda Kharkiv National Pedagogical імені Г. С. Сковороди, вул. Валентинівська, University, Valentynivska street, 2, Kharkiv, 2, Харків, Україна, 61000. Ukraine, 61000.

e-mail: anavolkova819@gmail.com e-mail: anavolkova819@gmail.com

Цитуйте цю статтю як: Ворожбіт-Горбатюк В.В., Волкова Я.В. Досвід Фінляндії щодо організації виховання батьків учнів: цільовий і змістовий компоненти. Теорія та методика навчання та виховання. 2019. № 46. C. 37-47. DOI: 10.34142/23128046.2019.46.03

Дата надходження статті до редакції: 24.04.2019

Стаття прийнята до друку: 07.05.2019 